E3S Web of Conferences 1, 20011 (2013)

DOI: $10.1051 / \mathrm{e} 3$ sconf $/ 20130120011$

(c) Owned by the authors, published by EDP Sciences, 2013

\title{
Sequential extraction partitioning of trace and nutrient elements in ashes from biomass firing district heating plants
}

\author{
M. Šyc ${ }^{1}$, M. Tošnarová ${ }^{1}$, J. Hrma ${ }^{2}$, M. Pohořelý ${ }^{1}$, K. Svoboda ${ }^{1}$ and M. Punčocháŕ ${ }^{1}$ \\ ${ }^{1}$ Environmental Process Engineering Laboratory, Institute of Chemical Process Fundamentals, Academy of Sciences of \\ the Czech Republic, v. v. i., Rozvojová 135/2, 16502 Prague 6 Suchdol, Czech Republic; syc@icpf.cas.cz \\ ${ }^{2}$ Faculty of Agrobiology, Food and Natural Resources, Czech University of Life Sciences Prague, Kamýcká 129,16521 \\ Prague 6, Czech Republic
}

\begin{abstract}
Four different ashes from three district heating plants firing biomass were studied with the respect to their potential application as soil fertilizers. Major and trace elements content and some important characteristics of the studied ashes are also presented. Five stage sequential extraction procedure was used for the determination of distribution and speciation of $\mathrm{As}, \mathrm{Ca}, \mathrm{Cd}, \mathrm{Cr}, \mathrm{Cu}, \mathrm{K}, \mathrm{Mg}, \mathrm{Na}, \mathrm{Ni}, \mathrm{Pb}$ and $\mathrm{Zn}$ in studied ash samples.
\end{abstract}

Keywords: Heavy metals, ashes, biomass, sequential extraction

\section{Introduction}

Biomass combustion in district heating plants of small and/or medium thermal output has recently increased in the Czech Republic. Consequently, the amount of produced biomass ashes has increased as well. Currently ca. 100000 tons of biomass ashes is produced in the Czech Republic, but in the future, the production up to 600000 tones is expected.

Biomass ashes contain significant amount of nutrient elements, hence their application as soil fertilizers is desirable. Except the nutrients, also some unwanted components (like heavy metals) are present in the ashes. These elements have to fulfill given legislative limits for their content in fertilizers. However, the legislative does not take into consideration real bioavailable and mobile fractions of given elements but only their total content, despite the fact that some forms and chemical species are very stable. Hence, the determination of traces and nutrients elements chemical speciation in biomass ashes is important for the evaluation of their potential application. One of the most common methods for the determination of elements speciation is the sequential extraction procedure (SEP) despite of its mentioned drawbacks (Filgueiras et al., 2002). This procedure can serve as an essential knowledge for the assessment of biomass ashes usage together with ashes elemental composition, physical-chemical properties and some other analyses (like XRD etc.). Some results of the SEP for biomass ashes can be found in literature (e.g. Nurmesniemi and
Pöykiö, 2006; Pöykiö et al., 2007) but the studied elements do not include nutrients and the extent of results is insufficient for the work out of some general conclusions. Therefore, the results of sequential extraction and other analyses for biomass ashes from 3 different district heating plants are presented in the study.

\section{Materials and Methods}

Four samples of ashes from biomass firing plants with grate furnaces were used in our study. Studied samples were:

- a bottom ash (S1) and a cyclone fly ash (S2) from a heating plant (output $2.5 \mathrm{MW}_{\text {th }}$ ) firing waste biomass from a nearby sawmill,

○ a mixed ash (S3) from a plant (output $1.7 \mathrm{MW}_{\text {th }}$ ) firing rape and grain straw,

o and a mixed ash (S4) from a plant (2 $\left.\mathrm{MW}_{\mathrm{th}}\right)$ firing waste biomass from wood processing factory.

The determination of dry matter content was carried out by overnight drying in an oven at $105^{\circ} \mathrm{C}$. The ash content was determined in a muffle furnace at $800{ }^{\circ} \mathrm{C}$ for 2 hours. The loss on igniton was determined in the muffle furnace at $550{ }^{\circ} \mathrm{C}$ for 2 hours.

The $\mathrm{pH}$ and solubility of ashes were determined in distilled water ( $\left.\mathrm{L}: \mathrm{S}=10,25^{\circ} \mathrm{C}, 1 \mathrm{~h}\right)$.

The contents of studied elements (As, Ca, Cd, Cr, $\mathrm{Cu}, \mathrm{K}, \mathrm{Mg}, \mathrm{Na}, \mathrm{Ni}, \mathrm{Pb}, \mathrm{Zn}$ ) were determined by a microwave digestion by $\mathrm{HNO}_{3} / \mathrm{HCl} / \mathrm{HF}$, subsequently, the digest was analyzed by ICP-OES. X-ray fluorescence analysis (XRF) was employed for the overview of total 
ash samples composition.

Sequential extraction procedure for the determination of selected element chemical speciation was realized in 5 steps according to a modified Tessier method (Tessier et al., 1979) with $5 \mathrm{~g}$ of pre-dried ash samples. Obtained fractions are water soluble, exchangeable, reducible, oxidizable and residual. In the first stage, $50 \mathrm{ml}$ of $1 \mathrm{M}$ sodium acetate were added to the sample and the mixture was shaken for $0.5 \mathrm{~h}$ at room temperature. Second stage consists of the addition of 50 $\mathrm{ml}$ of acetate buffer (acetic acid/sodium acetate, $\mathrm{pH}=5$ ) to solid residues from the first stage and shaking for $1 \mathrm{~h}$ at room temperature. In the third stage, solid residues from second stage were extracted in $20 \mathrm{ml}$ of $0.04 \mathrm{M}$ $\mathrm{NH}_{2} \mathrm{OH} \cdot \mathrm{HCl}$ in $25 \%$ acetic acid and heated at $96^{\circ} \mathrm{C}$ for 1 h. After that another $30 \mathrm{ml}$ of $0.04 \mathrm{M} \mathrm{NH} \mathrm{N}_{2} \mathrm{OH} \cdot \mathrm{HCl}$ in $25 \%$ acetic acid were added and sample was heated at $96{ }^{\circ} \mathrm{C}$ for $1 \mathrm{~h}$. In the fourth stage, $20 \mathrm{ml}$ of $30 \% \mathrm{H}_{2} \mathrm{O}_{2}$ acidified by $\mathrm{HNO}_{3}$ up to $\mathrm{pH}=2$ were added to solid residue and heated at $85^{\circ} \mathrm{C}$ for $1 \mathrm{~h}$, after cool down, another $20 \mathrm{ml}$ of $30 \% \mathrm{H}_{2} \mathrm{O}_{2}$ were added and heated again at $85^{\circ} \mathrm{C}$ for $1 \mathrm{~h}$. After cool down $20 \mathrm{ml}$ of $3.2 \mathrm{M}$ amonnium acetate in $20 \%$ $\mathrm{HNO}_{3}$ were added and shaked for $30 \mathrm{~min}$ at room temperature. The fifth stage consists of microwave acid disgestion of remained solid residue by $\mathrm{HNO}_{3} / \mathrm{HCl} / \mathrm{HF}$. Studied elements in obtained liquid extracts were determined by ICP-OES. The extraction of all samples was triplicated in order to obtain representative data.

\section{Results and Discussion}

Results of loss on ignition (LOI), $\mathrm{pH}$ and solubility of ash samples are presented in Tab.1. Good quality of combustion in all boilers can be concluded due to low LOI values. As expected, $\mathrm{pH}$ of all samples was basic due to high content of alkaline compounds of $\mathrm{Ca}$ and $\mathrm{K}$ (see tab. 2).

Tab.1 Loss on ignition, $\mathrm{pH}$ and solubility

\begin{tabular}{|l|c|c|c|}
\hline & LOI $^{\text {d }}$ (wt. \%) & pH & sl. $^{\text {d }}$ (wt. \%) \\
\hline S1 & 0.75 & 12.5 & 1.9 \\
\hline S2 & 1.9 & 12.6 & 3.8 \\
\hline S3 & 2.3 & 12.4 & 6.3 \\
\hline S4 & 0.56 & 12.4 & 2.7 \\
\hline
\end{tabular}

LOI - loss on ignition; $d$ - dry matter, sl - solubility

Ash forming elements contents in the form of oxides from XRF analyses are shown in tab.2 S1 and S4 ashes composition is typical for woody biomass with low content of $\mathrm{K}_{2} \mathrm{O}$ and $\mathrm{Na}_{2} \mathrm{O}$ and dominating alumino-silicate matrix. The ash S3 has different composition with higher portion of $\mathrm{K}_{2} \mathrm{O}$ which is characteristic for straw. Slight increase of $\mathrm{P}_{2} \mathrm{O}_{5}$ in $\mathrm{S} 3$ was caused by the combustion of rape straw. $\mathrm{S} 2$ is the only fly ash of the studied samples and its composition corresponds to that with the lowest content of alumino-silicates of the studied samples.
Obtained trace element contents of ashes are presented in Tab.3. Variety in their levels is given by the origin of ashes. As seen in Tab.3, volatile metals like $\mathrm{Cd}$ and $\mathrm{Zn}$ are more abundant in fly ash (S2) and on the contrary level of stable elements like $\mathrm{Cr}$ is higher in the bottom ash (S1).

Tab.2 Results of XRF analysis (all in wt. \%)

\begin{tabular}{|l|c|c|c|c|}
\hline & S1 & S2 & S3 & S4 \\
\hline $\mathrm{Na}_{2} \mathrm{O}$ & 1.33 & 0.356 & 0.958 & 1.91 \\
\hline $\mathrm{MgO}$ & 3.72 & 4.62 & 2.35 & 2.08 \\
\hline $\mathrm{Al}_{2} \mathrm{O}_{3}$ & 11.1 & 4.57 & 3.88 & 12.0 \\
\hline $\mathrm{SiO}_{2}$ & 36.5 & 12.7 & 45.7 & 54.8 \\
\hline $\mathrm{P}_{2} \mathrm{O}_{5}$ & 1.82 & 2.67 & 4.93 & 1.15 \\
\hline $\mathrm{K}_{2} \mathrm{O}$ & 5.95 & 6.60 & 19.6 & 4.98 \\
\hline $\mathrm{CaO}$ & 30.1 & 56.9 & 17.5 & 16.1 \\
\hline $\mathrm{TiO}_{2}$ & 0.795 & 0.400 & 0.270 & 0.610 \\
\hline $\mathrm{MnO}$ & 2.55 & 5.95 & 0.133 & 1.12 \\
\hline $\mathrm{Fe}_{2} \mathrm{O}_{3}$ & 5.10 & 2.78 & 1.77 & 4.29 \\
\hline$\sum$ & 99.0 & 97.5 & 97.1 & 99.0 \\
\hline \hline $\mathrm{S}$ & 0.169 & 0.643 & 1.47 & 0.390 \\
\hline $\mathrm{Cl}$ & 0.0460 & 0.154 & 0.568 & 0.124 \\
\hline
\end{tabular}

The results of sequential extraction are depicted on and Some variety of elements partitioning into five stages is obvious from the presented results for the studied ashes and elements. Water soluble compounds are extracted in the first stage. A significant extraction was found for $\mathrm{Na}, \mathrm{K}, \mathrm{Ca}$ and As. Specie that elute in the first stage are particularly chlorides and some of sulfates. Except them, elution of $\mathrm{Na}, \mathrm{K}$ and $\mathrm{Ca}$ can be ascribed to a good solubility of carbonates of these elements despite the fact that the second fraction is usually stated as a carbonate. However, carbonates of $\mathrm{Na}, \mathrm{K}$ and $\mathrm{Ca}$ are soluble in water and the acidification of solution such as for other carbonates dissolution is not necessary. A slight elution was observed for $\mathrm{As}$ and $\mathrm{Cr}$ which is caused probably by their pentavalent oxides dissolution. This is further strengthened by the facts that $\mathrm{Cr}_{2} \mathrm{O}_{5}$ is unstable at the temperature over ca. $300{ }^{\circ} \mathrm{C}$ and the highest $\mathrm{Cr}$ elution (ca. $5 \%$, from the rest ca. $1 \%$ ) was observed for the fly ash (S2) collected at much lower temperature than the other samples. Moreover, the As elution can be also caused by the dissolution of arsenates which were previously found in combustion residues (Shan et al., 2007).

In the second stage, the rest of $\mathrm{Ca}, \mathrm{K}$ and $\mathrm{Na}$ carbonates were released. Because of acid conditions also $\mathrm{Mg}$ carbonates were dissolved. None of the other studied elements were noteworthy extracted in this stage.

In the third stage, reducible compounds bound to $\mathrm{Mn}$ and $\mathrm{Fe}$ oxides are released. Large portion of bivalent metals such as $\mathrm{Cd}, \mathrm{Cu}, \mathrm{Ni}, \mathrm{Pb}$ and $\mathrm{Zn}$ were extracted in this stage probably because they are present in the ashes 
Tab.3 Selected elements content in dry matter of studied ashes (all in $\mathrm{mg} / \mathrm{kg}$ )

\begin{tabular}{|c|c|c|c|c|c|c|c|}
\hline & As & Cd & Cr & Cu & Ni & Pb & Zn \\
\hline S1 & 14.2 & 1.57 & 228 & 995 & 118 & 115 & 407 \\
\hline S2 & 13.4 & 16.5 & 72.6 & 211 & 86.0 & 35.8 & 1310 \\
\hline S3 & 12.7 & 1.19 & 110 & 61.9 & 60.7 & 16.1 & 139 \\
\hline S4 & 22.8 & 1.59 & 126 & 79.0 & 63.3 & 34.7 & 330 \\
\hline
\end{tabular}
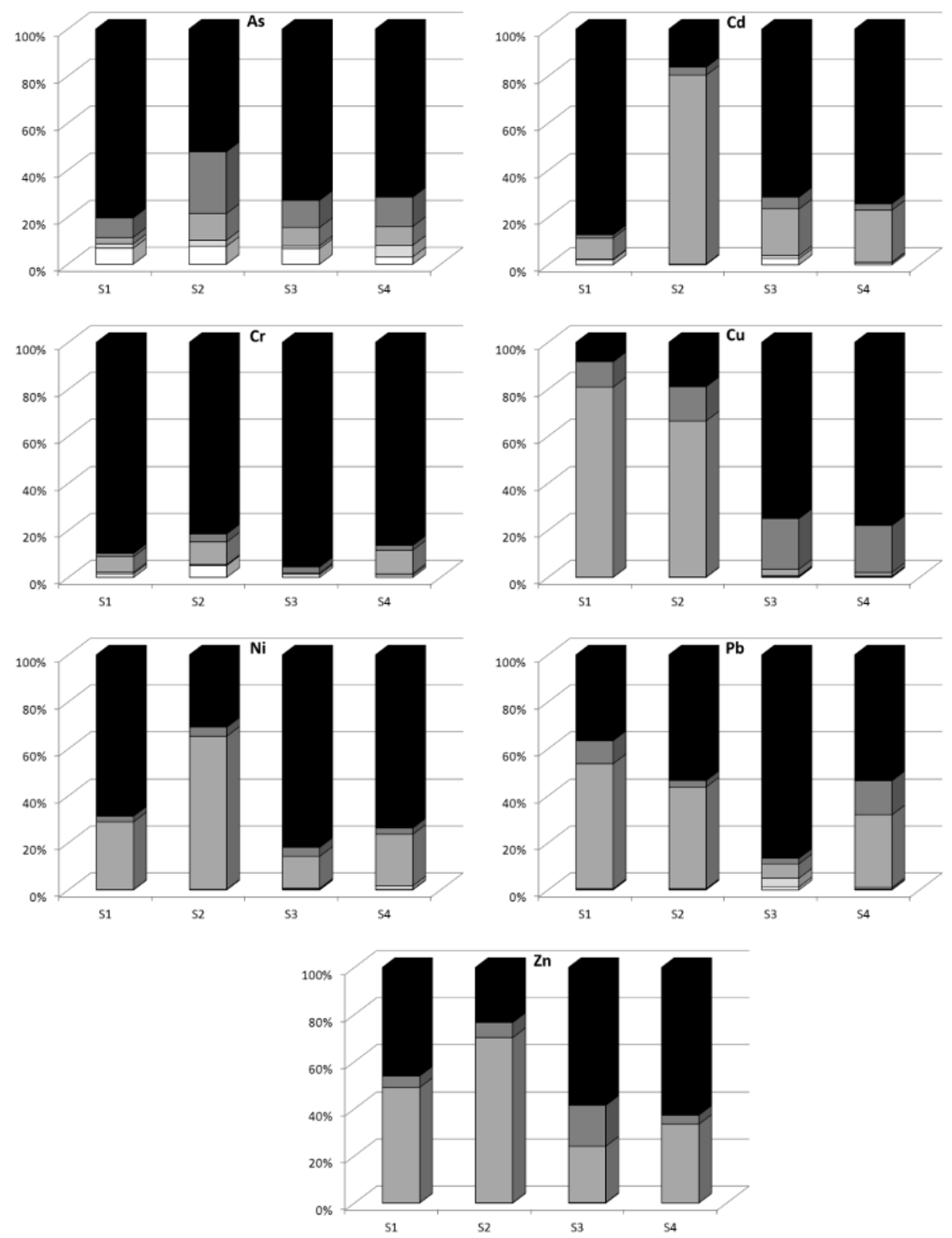

$\square$ Stage $1 \quad \square$ Stage $2 \quad \square$ Stage $3 \quad \square$ Stage $4 \quad \square$ Stage 5

Fig.1 Results of sequential extraction procedure for trace elements

as mixed and/or individual oxides. From the results can be concluded that the rate of elements extracted in this stage is given also by the total amount of Fe, Mn-oxides (see).
The highest portion of Fe, Mn-oxides were found in S2 the highest elution of above mentioned metals were found from S2 as well.

Sulphides, organically bound elements and other 
oxidisable species should be eluted in the fourth stage. Noteworthy amount was found for $\mathrm{As}, \mathrm{Cu}$ and in some cases of $\mathrm{Ca}, \mathrm{Mg}, \mathrm{Pb}$ and $\mathrm{Zn}$ in this stage. The highest content of $\mathrm{S}$ was found in $\mathrm{S} 3$ for which the highest elution of $\mathrm{Cd}, \mathrm{Cu}, \mathrm{Ni}$ and $\mathrm{Zn}$ was also found in the fourth stage of the studied samples as well. The residual fraction was the prevailing one for the majority of studied elements and ashes combination. However, it can be expectedly concluded that in the fly ash elements partitioning is leveraged towards mobile fractions in the comparison with the bottom ash. The first three stages are sometimes highlighted as mobile ones whereas the last two as stable ones. $\mathrm{As}, \mathrm{Cr}$ and $\mathrm{Mg}$ can be noted as stable elements based on this distribution. With some exceptions also $\mathrm{Cd}$ and $\mathrm{Cu}$ can be evaluated as stable. $\mathrm{Cd}$ was found as a mobile in the fly ash only. $\mathrm{Cu}$ was in $\mathrm{S} 3$ and S4 completely stable (more 97\%) while in S1 and S2 was found predominantly in the mobile third stage.

\section{Acknowledgements}

The authors thank the financial supports providing from Technology Agency of the Czech Republic (Project TA01020366).

\section{References}

Filgueiras AV, Lavilla I, Bendicho C. Chemical sequential extraction for metal partitioning in environmental solid samples. J Environ Monitor. 2002; 4:832-857.

Nurmesniemi H, Pöikiö R. Leachability of Metals in Grate-Fired Boiler Wood Ash from a Small Municipal District Heating Plant (6 MW). J Residuals Sci Tech 2006; 3:217-225.

Pöikiö R, Nurmesniemi H, Dahl O. Concentrations of Nutrients and Heavy Metals in Cyclone Fly Ash from the Grate-Fired Boiler at a Small Municipal District Heating Plant (6 MW). J Residuals Sci Tech 2007; 4:127-136.

Shah P, Strezov V, Stevanov C, Nelson P. Speciation of Arsenic and Selenium in Coal Combustion Products. Energy\&Fuels 2007; 21:506-512.

Tessier A, Campbell PGC, Bisson M. Sequential Extraction Procedure of the Speciation of Particulate Trace Elements. Analytical Chemistry 1979; 51:844-851 